\title{
African Motherhood: A Panic History in The Bluest Eye and Beloved
}

\author{
Mukhtar Ahmad Ganie \\ Barkatullah University \\ Bhopal, Madhya Pradesh, India \\ greenvalley235@gmail.com
}

\section{Dr. Shubhra Tripathi}

Professor and Head Department of English

Govt Motilal Vigyan Mahavidyalaya

Bhopal, Madhya Pradesh, India

shubh60@yahoo.co.in

Abstract:

Mother is a bonus bestowed upon humanity by Almighty Allah as she can claim all the calamities for her children to make them safe. The importance of mother as suggested by Prophet Mohammad (PBUH) If I (PBUH) would have been in prayer (Salat) and she (Mother) had called me, I (PBUH) would have left my prayer to listen to her first and then I would have completed my prayer. Here it shows the essence of mother, as she is the source for a man to claim the heaven. Nissim Ezekiel in one of his poems says, 'Thank God! Scorpion picked on me and spared my children' this shows that she can suffer the pain of poison to make safety of her children possible. African motherhood is a paradigm for mothers all over the world. These black mothers have suffered sexual abuse during the period of slavery to save their wards. They worked very hard and even sometimes murdered their children to save them from slavery and sexual assault from the rich white masters. Same 
thing can be seen in the novels of this study. This research paper will explore the circumstances that compelled mothers to sacrifice their wards and suffer the pangs for whole life. Importance of motherhood will be explored here.

Keywords: Mother, Calamities, Paradigm, Assault, Sacrifice

Introduction

Mother is the fountain and conduit of creation; she is a blessing upon humanity by the Almighty Allah. She can go to any extent to save her children from any situation that tries to harm them, whether she dies or lives she wants to secure her children from every hazard such as natural or manmade. Today when the world is making progress in every aspect at a very fast speed and transformation is taking place in everything and everyone, the only thing that remains unchanged and constant is the mother's love for its children. "A housewife is a transformer of natural products into cultural ones. Being responsible for preserving the boundaries between natural and cultural life, she shifts matter out of place into matter in place" (Douglas 1969:40). She is a caretaker of the house where she can make raw and rotten into ripe, implying individual can be produced by her with the etiquettes of society, culture and an adamite can be made a good human as well as a responsible citizen. Mothers are not scarce but motherhood lacking may totally damage the individual, community and so the world.

Review of Literature

"Since father is a missing figure in black community mother became the head and their relationship with their sons and daughters are always puzzling" (Bh. V. N. Lakshmi and Zainab Abdul Aziz Al Suhaibani 41).When we talk about the motherhood in African literature Toni Morrison comes to our lips for she has presented the tale of pain that African mothers suffered during the slavery period. The relation between the parents and their wards 
was often presented as complex, sometimes mothers are aliens and at other times wards seem unconventional.

"The African American tradition of motherhood centres upon the recognition that mothering, in its concern with the physical and psychological wellbeing of children and its focus upon the empowerment of children, has cultural and political import, value, and prominence, and that motherhood, as a consequence, is a site of power for black women"(Andrea O' Reilly 5). It is where mother looks to physical care of our children and to enhance the wards from all sides Andrea focuses on political value which gives power to motherhood.

"Adrienne Rich...about motherhood being an institution which is controlled by men. She has argued that there are two meanings of motherhood. ...two meanings of motherhood, one superimposed on the other: the potential relationship of any woman to her powers of reproduction and to children; and the institution, which aims at ensuring that the potential - and all womenshall remain under male control." (Rich 17)

This view implies the subjugated role of women as living not for themselves but for others such as their children, husband and their in-laws or society. It is the view of subaltern where self has no place at all and she is looked upon as other, here we can see the split because women have to restrict their sexual desire, women are the mixture of their physical self and their duty for their families so both of them should meet in women. According to Sarah Grand, "women who do not consider marriage, and, motherhood as their only outlet are New Women, "...she solved the problem and proclaimed for herself what was wrong with Home-is the- woman's sphere, and prescribed the remedy" (Grand 271). Sarah says that it is not marriage only that is women's duty, their sphere is not only home but self and society, 
they must live for themselves and for society. New women have broken the narrow walls and came out to live their lives as liberated women who do not believe in living of women in walls. "Motherhood, for Morrison, is a site of liberation and self-realization, because her standpoint on motherhood is developed from black women's everyday practices and meaning of motherhood wherein motherhood is a site of power for black women" (Andrea O' Reilly 20). It may be an experience of Morrison that had taught her the real meaning of motherhood and how it works for a mother. Commenting upon Morrison's view of mother, Andrea O' Reilly says that mother looks for the protection and wellbeing of her children both physical and psychological. This concept is important politically and culturally and motherhood for Morrison gives power to women to enhance them especially black women. Women must not be locked in chains or their self should not be drained from them.

"If women are to become full, complete, the answer may not be in the future, but the answer may be back there. And that does interest me more than the fully liberated woman, the woman who understands her past, not the woman who merely has her way. Because that woman did know how to nurture, and survive ... The most respectable person is that woman who is a healer and understands plants and stones and yet they live in the world. ... She could nurse, she could heal, she could chop wood, she could do all those things. And that's always been a pejorative word, a bad thing, but it isn't." (Taylor-Guthrie 81-82)

Women can be women if they are good mothers, there must be essential qualities of motherhood in them, they should take lessons from their past, they have to take care of their relations. They must cure, have to do household work well, foster their children and there must be every expertise in them. They have to take control of every good or bad condition. 
"When we say about "mothering is to highlight the active nature of maternity: an important move, given the traditional view in western culture of the mother as passive and powerless" (Emily Jeremiah 21-22). This quote displays that mother is an active word, a verb that keeps on doing for her family and community and she cannot be passive, active motherhood can be seen in case of Sethe in Beloved.

"A woman becomes a birth giver under many circumstances. It can be her own choice, it can be a compulsion, it can be the institution of motherhood and she can also be a birth giver being a victim of rape. All these do not make her a mother. In order to be a mother a person needs to work on the skills of being a proper mother. The new concept of motherhood dismisses the genderconstructed notion of motherhood. This new notion of motherhood provides the scope of motherhood to all genders." (Tanjim 28)

So the mother is a person who is the soul of the family, it is because of her that we see good citizens and good community. She must have all the potential of a good mother. She must not be like Mavis or Pauline but like Sethe who gave her all for her daughter or like Mrs. Mac Teer who cares Pecola like her own child.

The Bluest Eye: An Overview

The maiden novel of Morrison actually is a pathetic story of 11 year old weak, black girl but role of a mother in character of Pauline who made possible her daughter's madness is a finest one. "The extremity of Pecola's case stemmed largely from a crippled and crippling family - unlike the average black family and unlike the narrator's. But singular as Pecola's life was, I believed some aspects of her woundability were lodged in all young girls" (The Bluest Eye 6-7). It is how the misery of young daughters is told by Morrison in the very first book that she wrote. It is an account of whole Africa where young girls became the victims of rape, sodomy, oppression, suffering and melancholia. She was made the mother but she has 
no clue what motherhood or mother is? "The tightness of her vagina was more than he could bear" (The Bluest Eye 124-125). What more could have been suffered by the child? She would have endured a lot of pain that could have been unbearable, even the novelist is feeling the soreness and readers feel it by wetting their eyes. It is sexual harassment of a girl by her father which panics the heart and mind of all who read it. "Removing himself from her was so painful to him he cut it short and snatched his genitals out of the dry harbor of her vagina. She appeared to have fainted" (The Bluest Eye 125). This quote shows how much brute was the father who exploited his unripe child, drunk with the sexual desire he made his child a victim of his lust. It was hard for the child because father doing it to her would have been much more painful. And in addition to that she was not a girl of mature age and at that stage she didn't even knew the meaning of sex.

"I don't mean about the first time. I mean about the second time, when you were sleeping on the couch. I wasn't sleeping! I was reading! You don't have to shout. You don't understand anything, do you? She didn't even believe me when I told her" (The Bluest Eye 125). This is the double rape of a daughter by her father and Pecola is telling her misery to her friends Claudia and Frieda who were her companions and she would have thought of some consolation may come from them.

"Cholly while committing the incest (horrendous crime) when he was drunk didn't even think of the age of his daughter. He just like an animal filled with beastly desires took an undue advantage of the innocent girl. Rape is of course an offence legally but this act was child sexual abuse criminal was not a villain or rogue whose aim is to bring ignominy on him but he was the father of the child." (Mukhtar Ahmad and Shubhra Tripathi 56)

These lines from the paper explain the brute and animal instinct of Cholly Breedlove. He was not a human but an animal who didn't even spare his 11 year old daughter. It is not 
only the case of rape but incest he must have been punished and mother must have come to aid her ailing child. When something unusual happen to girls, they escape to their mothers but for Pecola there was no outlet and no way out. "You don't understand anything, do you? She didn't even believe me when I told her" (The Bluest Eye 125).Telling about her suppressed self to her friends Pecola says that her complaint was not heeded by her mother though she tried to tell her about the rape she has undergone. Mother is all the while missing for Pecola. Mother and daughter have fallen apart from each other.

“So that's why you didn't tell her about the second time? She wouldn't have believed me then either. You're right. No use telling her when she wouldn't believe you" (The Bluest Eye 125). The only thing Pecola could have done is that she would have explained everything to her mother but Pauline Breedlove was not taking note her point. She was not even listening to her child. So for our little innocent black girl's the situation was wicked and worsened. "Into her son she beat a loud desire to run away, and into her daughter she beat a fear of growing up, fear of other people, fear of life" (The Bluest Eye 98). Pauline was mother but her desire to live in Fisher's house and live for them has made her dry and her children lost the love they needed at that time and the result was gruesome and sad. Sammy ran away and Pecola suffered as other in her own house it seems that she was an African black being marginalized by the whites though the reality was something else.

"Mrs. Breedlove knocking Pecola down and soothing the pink tears of the frozen doll baby that like the door of our icebox" (The Bluest Eye 142). Pecola was beaten by her mother and she was calling her by the name of Mrs. Breedlove that was a gap between the daughter and mother. So the communication gap has prevented Pecola to tell her misery to her mother. It was disgusting and distraught. Mother is not a mother but an enemy of her daughter. Should mothers do that to their daughters? Where can a daughter go when mother is ignorant? 
"No!" He pushed her down, ran out the door that separated the rooms, and held it shut with his hands. Pecola's banging on the door increased his gasping, high-pitched laughter" (The Bluest Eye 71). This shows how she was treated by outsiders so the frustration was mounting on her day by day and she was losing her consciousness. Junior made the increase of anxiety possible while it was strengthened by the Holy man, school teachers, shopkeeper and others. At last she became mad. Pecola was lost but if mother's care would have been there, she would have been saved. "Her calling Mrs. Breedlove Polly, when even Pecola called her mother Mrs. Breedlove, seemed reason enough to scratch her" (The Bluest Eye 84). Such was the reason why was rift there. Pecola called her by the name of Mrs. Breedlove which further aggravated their torn relationship while Pauline was engrossed in movie world and never felt the pain of her daughter though we see she wants Cholly to be severely punished for his crime, she calls him the beast and animal, motherly instinct came to the front but otherwise she and her daughter seem to be aliens to each other. "Strike the bastard down from his pea-knuckle of pride" (The Bluest Eye 35). This is how she wishes her husband should receive his punishment. She is a good housekeeper but not a good mother. Was it her desire or compulsion? She must have been a mother for her daughter in the time when Pecola was devastated.

Pauline is ignorant of her children but all other mothers are very much concerned about their children.

"But she is brutally raped by her father, bears a child that dies and retreats into madness believing that her eyes are not simply blue but the bluest of all. Dicing with class, race and gender, Pecola encounters no ladders but only snakes in her life. Left in the spring with the burden of rape, Pecola resorts to madness, the only refuge available to her." (Bh. V. N. Lakshmi and Zainab Abdulaziz Al Suhaibani 41) 
Why our heroin lost her mind, the reason is that her mother remained at bay from her, Pauline was not a mother at all, if there would have been anything like mother in her then like a woman she would have fought from the side of her daughter and not with her daughter. Pecola was unfortunate and Pauline was an ignorant and a compelled mother. Pecola had seen nothing that could heal her. Her struggle was a failure because the most precious mother was not there for help. She desired bluest eyes in the valley of romance and that was impossible.

"No doubt, despite her obsession with so called fair complexion of white people and finery of their behavior, Pauline loves her daughter Pecola and protected her to the best of her ability. But when it comes to choose between her job and expression of love for her daughter, she prefers the former and that virtually orphaned Pecola." (Bh. V. N. Lakshmi and Zainab Abdulaziz Al Suhaibani 44)

Pecola was the only one who could have protected herself and that was her defeat. Sancho Panza's were there for her but the psychological damage had deep tarnished her soul and nothing was left there for her. The mother and daughter seemed falling apart and this has done much greater damage to the psyche of the child and she lost her mind. Pauline was not mummy but Mrs. Breedlove. Pecola was nothing for her that made pain all the more panic and wound of Pecola's psyche became cancerous for which no cure was possible.

This novel is about the relation of a mother and daughter where there seems no affinity between the two. They are poles apart as two sides of a sea. But still the feelings of mother in Pauline are not invisible. She becomes angry and prays for God's wrath for her husband when Cholly's crime becomes known and that is power and affliction of motherhood. Mother did not die in her but the fantasy world she was living in took away motherly feelings from her. 


\section{Beloved: An Analytical Study}

Morrison's mothers are ready to sacrifice their daughters to get freedom for their children. "When Sethe tries to explain to Beloved why she cut her throat, she is explaining an anger handed down through generations of mothers who could have no control over their children's lives, no voice in their upbringing" (Hirsch, M. 196). Here the motherhood is trying its level best to make possible the security of the children and especially the daughters by showing them passion and love of mothers for their children. Killing a daughter is not a crime for a parent when there is danger for sexual abuse. "In Morrison, however, there are profound differences between being a woman and being a mother. For one thing, there is the question of masculine desire. Sethe is frightened when Paul D asks her to have his baby. Perhaps the central problem, in fact, is the lack of the very selflessness on the part of a mother-to-be that Stowe takes for granted" (Terry Paul 113). She is the one like one in Ezekiel's Night of the Scorpion. She can bear the burden of rape on herself but not on her Beloved daughter. She is a new liberated woman who wants house, honour, free life and equality for her children. Seth wants to be a good mother and to secure her children that are the reason why she denied Paul D's offer of love and marriage, she would have got a good life with Paul D. But her motherhood for her children was what she lingered on to. She was a committed mother who thought of her children at every stage.

"Needing to be good enough, alert enough, strong enough, that caring - again. Having to stay alive just that much longer. O Lord, she thought, delivers me. Unless carefree, mother love was a killer" (Beloved 132). This quote from Beloved explains that mother has to be very careful, Sethe prays to God to help her to remain as a mother though she was much tired of motherhood. "Feel too much!" cries Mrs. Shelby early in the novel. "Am I not a woman- a mother?" (Uncle Tom's cabin 87) What is the difference between a mother and woman: can 
be understood by the character of Sethe when she denied love for her children for the sake of motherhood.

Sethe has only spoken to her mother once and she was sold at the age of 11 by her family. Sethe not only proved a good mother but a real woman, she can be labeled as a real mother. She saved her children by endangering her own life. She fled the plantation because she was sexually exploited there. Her milk was suck by two nephews of school teacher and they made a tree mark on her back. She didn't want the same for her children especially for her daughters.

"In Beloved what a woman is has become hopelessly lost in what a mother is, and what a mother is has become haplessly entangled in what a child is" (Terry Paul Ceasar 117). Sethe was a woman, her desire was having no value in front of her motherhood and thus she was lost to motherhood. She was a slave by profession who was married to Halle, they had children. When her husband disappeared from the scene she took the steering of her house and became breadwinner. When school teacher came to take her back she killed her Beloved. She didn't kill her to please herself. She has no grudge against her daughter but to save her from sexual abuse. She is a woman who is much aware of the honour and esteem of her daughter so she took the murderous step. It was only way open to her for the redemption of her daughter.

As per the view of Collins what mothers are, "Biological mothers or bloodmothers are expected to care for their children? But African and AfricanAmerican communities have also recognized that vesting one person with full responsibility for mothering a child may not be wise or possible. As a result, "othermothers," women who assist bloodmothers by sharing mothering responsibilities, traditionally have been central to the institution of Black motherhood." (Collins b 47) 
If this has to be mother and if she is viewed like that, can we say that Sethe has done anything against the notion? She was the biological mother of her daughter and what she did to her daughter was justified because her aim was to save the honour of her daughter.

"It's my job to know what is and keep them away from what is terrible. I did that"(Beloved 194). When Sethe talks with Paul D. she says no matter how but I must protect my children from all that is harming and dangerous for them. She wants care and wellbeing of her children, she didn't want her daughter to be news and people learning about her rape so she did what seemed apt to her. Any woman in her place could have done the same.

"No more powerful than the way I loved her", (Beloved .4). Seth's love for her daughter was deep and mother was there in her mind as well as in her heart. "I will protect her when I'm live and I'll protect her when I ain't" (Beloved 54). Sethe here directly becomes a pure mother when she thinks to protect her children whether she is alive or dead. It is an indication of a pure selfless mother love. She has denied enjoying sexual pleasures and life with Paul D. and was looking how to enable her ward's safety and work for their wellbeing. Telling her daughter about her love Seth says, "I went and got you a gravestone, but I didn't have money enough for carving, so I exchanged sex" (Beloved 216). This is how much Sethe has suffered and how much humiliation she has undergone for her daughter. African motherhood is to save children and Sethe has sold her honour to keep intact the esteem of her Beloved. What could have she done? She has to humiliate herself for her daughter because she was short of money and society exploited her as it has happened in the society before. "The newly arrived women are homeless, exploited, and hysterical daughters, or mothers" (Paradise 11). These lines from Paradise display why these women were rebels because in one way or the other they have been exploited sexually either by their husbands or boyfriends or by the outside world. Mavis has left her children and husband wondered over there but see Sethe in Beloved lost her everything for her daughter. 
"Beloved becomes a testimony to those ancestors whose presence continues to endure and demand the love and recognition of its progeny in order to survive" (Ganie M and Javaid 3368). In this book Morrison has a staunch message for humanity and that is how mothers work, though Sethe is all the while panic but she stands for her children and never lets their expectations down. She wants respect for this motherhood. Look at the Pauline who beats her daughter and never listens to her but Sethe gave her body to save the honour of her child. Pecola lost her virginity at the hands of her father and her mother pays least attention to her but Beloved is really the marvel for Sethe. "Slave mothers sometimes killed their children to prevent them from leading a shameful life of slavery and suffering" (Ganie M and Gautam 2271). This was the measure that Sethe has taken and in this way her daughter lost life and later Sethe had to pay the price for the same. Was she not a mother or a woman? She must be respected and that is what African mothers stand for.

Result

Lack of motherly love can make anyone insane; such is the case with Pecola.

Two novels selected for study show the contrast of mothers and motherly love.

Blackness is treated to be wicked by whites but African black mothers are sweet and they seem to be more like Asian mothers.

Motherhood is a blessing everywhere on this earth whether human or animal mother is caring, loving, passionate and hardworking. She can even sell her honour to save her children and this point is evidenced by Sethe in Beloved.

Conclusion

The Bluest Eye and Beloved present the picture of motherhood from varied angles; Pauline is a mother but very far away from the instincts of motherhood. It may be her poverty, rift with her husband or the romantic notion that divulges her of the blessing of mother love. But when we see Sethe we are amazed and compelled to say that mother is and 
must be like this. Though she had killed her daughter with the saw by cutting her throat but still she is an example of a good mother. Pauline and Sethe are two mothers with distinct notions though we can say they both are mothers. These novels present the pathetic picture of mothers of Africa and through them Morrison has urged the world to look keenly to the problems and save the mothers and motherhood. 


\section{Works Cited}

Collins, Patricia Hill. "Shifting the Center: Race, Class, and Feminist Theorizing About Motherhood." Mothering: Ideology, Experience, and Agency. Ed. Evelyn Nakano Glenn, Grace Chang, and Linda Rennie Forcey. New York: Routledge, 1994. Pp, 4565

Douglas, Mary Tew. 1969. Purity and Danger: An Analysis of Concepts of Pollution and Taboo. London: Routledge, 1966.

Emily Jeremiah. Motherhood to Mothering and Beyond Maternity in Recent Feminist Thought, Journal of the Association for Research on Mothering. The Legacy Qdrienne Rich's "Of Woman Born." Ed. Andrea O' Reilly. New York: SUNY. 2004. Pp, 59-71

Ganie, Mukhtar Ahmad and Shubhra Tripathi. Humanism evoked through the Protagonist in 'The Bluest Eye, Asian Studies, Volume 37, Issue 1, January-June-2019. Pp, 54-59 and Javaid Ahmad Tantry. Humanism in the Selected Fictional Works of Toni Morrison, International Journal of Research, Volume 04 Issue 13, October 2017. Pp, 3357-3370

G. S. Gautam. The Pangs of Women in Toni Morrison's Beloved, Think India Journal, Volume 22, Issue 4, 2019. Pp, 2270-2278

Grand, Sarah. The New Aspect of the Woman, Question North American Review Mar. 1894. Pp, 270-276

Hirsch, M. The mother/daughter plot, Bloomington: Indiana University Press, 1989.

Lakshmi, Bh. V. N. and Zainab Abdulaziz Al Suhaibani. Dicing with Class, Race and Gender: Toni Morrison's The Bluest Eye, International Journal of Humanities and Social Science Invention, Volume 4, Issue 1, January. 2015. Pp, 40-46

Morrison, Morrison. Paradise, New York, Toronto: Alfred A. Knopf, 1998. 
Beloved, New York: New American Library, 1987. Print.

O’ Reilly, Andrea. Toni Morrison and Motherhood A Politics of the Heart, State University New York Press, 2004. Dissert.

Paul, Caesar Terry. Slavery and Motherhood in Toni Morrison's Beloved, www.jstor.org. This content downloaded on Sun, 20 Jan 2013. 18:44:32 PM, Pp, 111-120

Rich, Adrienne of Woman Born: Motherhood as Experience and Institution. New York: W.W.Norton, 1976. Print.

Stowe, H. B. Uncle Tom's cabin, New York: Penguin Books, 1981. Print.

Taylor-Guthrie, Danille. Conversations with Toni Morrison, Jackson: University Press of Mississippi, 1994. Pp, 81-82

Tanjim, Taslima. Portrayal of Motherhood by Female Authors in American Literature in the Light of the Awakening, Herland and the Narrow House, 2016. Dissert.

www.Archive.Org/Stream/Thebluesteyefulltextjamessutton/The\%20Bluest $\% 20$ Eye_Full\%20 text\%20-\%20JAMES\%20SUTTON_Djvu.Txt 